\begin{tabular}{|c|c|c|c|c|}
\hline $\begin{array}{c}\text { Jurnal Penelitian \& } \\
\text { PPM }\end{array}$ & ISSN: 2442-448X & Vol 4, No: 2 & Hal: $129-389$ & Juli 2017 \\
\hline
\end{tabular}

\title{
PROGRAM PELAYANAN KEUANGAN MIKRO LEMBAGA BINA SWADAYA DI KECAMATAN KIARACONDONG BANDUNG
}

\author{
OLEH: \\ USWATUN HASANAH ${ }^{1}$ \& RISNA RESNAWATY 2 \\ 1. Mahasiswa Program Studi Magister (S-2) Ilmu Kesejahteraan Sosial FISIP Universitas Padjadjaran \\ 2. Departemen Kesejahteraan Sosial FISIP Universitas Padjadjaran
}

Email:

(uswatun.ks09@gmail.com; risna.resnawaty@unpad.ac.id)

\begin{abstract}
ABSTRAK
Permasalahan kemiskinan yang belum juga tuntas pada masyarakat perkotaan dan perkotaan mendorong lahirnya berbagai program pengentasan kemiskinan. Berbagai upaya dilakukan oleh pemerintah agar masyarakat bisa hidup secara layak. Program Pelayanan keuangan Mikro adalah program yang ditujukan bagi UMKM agar mereka bisa mengembangkan usahanya. Pada Program yang dilaksanakan oleh Lembaga Bina Swadaya ini terlihat peran Community Worker memiliki peran yang penting agar kolektabilitas dari pengembalian dana bergulir menjadi lancar. Yang menarik pada program ini adalah adanya pembiasaan menabung sehingga UMKM memiliki dana untuk menambah modal maupun untuk memenuhi kebutuhan lain di luar usaha. Sayangnya program ini tidak disertai dengan pendampingan. Sehingga, UMKM tidak mendapatkan pengetahuan dan keterampilan baru untuk menjalankan usahanya.
\end{abstract}

\section{Kata Kunci : Usaha Mikro, Pelayanan Keuangan, Bina Swadaya}

\section{PENDAHULUAN}

Besarnya jumlah penganggur dan angkatan kerja tersebut tidak diimbangi dengan pertumbuhan usaha besar (industri), yang notabenenya sebagai penyerap angkatan kerja. Menurut data pada tahun 2015 terdapat 2635 perusahaan yang tutup, pada saat yang sama hanya 2.018 perusahaan yang baru tumbuh. Selisih angka tersebut menunjukkan pertumbuhan industri yang minus $2 \%$ dari total industri yang ada (Kompas, 13Desember 2015:7). Kondisi ini mendorong terciptanya lapangan kerja alternatif guna memperoleh penghasilan dan pemenuhan kebutuhan, yaitu usaha mikro.

Selama kurun waktu tahun 2014-2015, terjadi peningkatan terhadap jumlah unit dagang kecil non formal sebesar 880 unit dan terjadi jumlah tenaga kerja sebesar 6.718. Pada tahun 2014 tercatat ada 52,76 juta unit usaha mikro, dengan jumlah tenaga kerja sebesar 96,21 juta jiwa (Kompas, 1 April 2015:47). Meningkatnya jumlah unit usaha berimbas pula terhadap tenaga kerja yang terserap. Hal ini tentunya dapat mengurangi jumlah masyarakat yang menganggur. Selain mendapatkan pekerjaan, masyarakat juga memperoleh penghasilan dari usaha mikro. Penghasilan ini kemudian digunakan untuk memenuhi kebutuhan sehari-hari.

Meningkatnya jumlah usaha mikro bukan berarti usaha ini tanpa kelemahan. Keterbatasan permodalan seringkali menjadi penghambat usaha mikro untuk meningkatkan skala usahanya. Meningkatnya jumlah kebutuhan dan harga kebutuhan tersebut, membuat usaha mikro harus meningkatkan modal usahanya. Pengelolaan keuangan usaha mikro umumnya masih berbaur antara modal usaha dengan konsumsi. Tidak jarang modal usaha digunakan untuk konsumsi, seperti 


\begin{tabular}{|c|c|c|c|c|}
\hline $\begin{array}{c}\text { Jurnal Penelitian \& } \\
\text { PPM }\end{array}$ & ISSN: 2442-448X & Vol 4, No: 2 & Hal: $129-389$ & Juli 2017 \\
\hline
\end{tabular}

memenuhi kebutuhan sehari-hari, pendididikan, kesehatan atau kebutuhan lainnya. Kondisi ini membuat pengusaha mikro sering mengalami kesulitan modal ketika akan memulai usahanya kembali, sehingga menghambat keberlangsungan usahanya (Sjaifudian, 1995:59).

Menurut manual pengelolaan kantor cabang, program pelayanan keuangan mikro Bina Swadaya menggunakan model yang diadopsi dari Grameent Bank yang dilakukan oleh Muhammad Yunus di Bangladesh. Ciri khas dari pelayanan keuangan model ini yaitu, tidak mensyaratkan agunan dan keanggotaan kelompoknya diharuskan perempuan. Kegiatannya tidak hanya pemberian kredit saja, ada pula kegiatan menabung yang wajib diikuti, serta pelayanan penghapusan pinjaman dan pemberian asuransi (uang kerohiman) jika peserta program meninggal dunia.

Program pelayanan keuangan mikro Bina Swadaya salah satunya dilakukan di kecamatan Kiaracondong. Kecamatan Kiaracondong merupakan wilayah yang potensial untuk kegiatan usaha mikro. Potensi tersebut dapat dilihat dari adanya stasiun kereta api, pasar dan pabrik. Tempat-tempat ini selalu ramai dilalui masyarakat, sehingga menyuburkan kegiatan sektor informal seperti pedagang eceran, pedagang kaki lima, warung, dan sebagainya. Tercatat ada 12 kelompok yang mengikuti program ini, dengan jumlah rata-rata anggota pada setiap kelompoknya sebanyak 15 orang.

\section{PEMBAHASAN}

Model MPK (Masukan - Proses Keluaran) yang dikemukakan oleh Sheafor, Horejsi dan Horejsi (Suharto, 2009:186-187). Berikut ini merupakan komponen dari model tersebut:

1. Masukan adalah karakteristik kelembagaan, termasuk sumbersumber atau sarana dan prasarana yang dimiliki oleh lembaga, yang mendukung dalam memberikan pelayanan dan mencapai tujuan-tujuan lembaga. Ada empat aspek yang diperhatikan dalam menilai masukan:

- Availability yaitu, apakah jumlah dan jenis pelayanan yang diberikan oleh lembaga sudah cukup tersedia untuk memenuhi kebutuhan klien?

- Accessibility yaitu, apakah lokasi, biaya dan waktu pelayanan mudah dijangkau oleh klien dan kelompok sasaran? Adakah kelompok-kelompok lain yang potensial menjadi klien lembaga yang tidak memperoleh pelayanan?

- Responsiveness yaitu, apakah prosedur lembaga dan pelayanannya dapat merespon kebutuhan masyarakat?

- Relevance yaitu, apakah jenis pelayanan lembaga sudah sesuai dengan kebutuhan klien?

2. Proses adalah segenap prosedur yang diterapkan lembaga dalam memberikan pelayanannya terhadap klien. Ada dua aspek dalam menilai proses pelayanan lembaga:

- Productivity yaitu, apakah sumber-sumber yang digunakan untuk mencapai tujuan-tujuan lembaga telah sejalan dengan prinsip efisiensi?

- Perfomance apakah perilakuperilaku kerja para pegawai lembaga telah sesuai dengan standar profesional?

3. Keluaran adalah karakteristik klien pada saat lembaga selesai memberikan pelayanan terhadap klien. Aspek dalam kategori ini yaitu,

- Service Effectiveness apakah pelayanan yang diberikan lembaga terhadap klien secara kausal berkaitan dengan pencapai tujuan-tujuan pelayanan?

\section{Pembahasan}

\section{Tahap Pemilihan Area}

Tahapan pemilihan area merupakan tahapan pertama dalam memulai program pelayanan keuangan mikro Bina Swadaya. Dilihat dari aspek availability, kegiatan ini tidak rutin dilakukan. Kegiatan ini hanya dilakukan apabila ada masyarakat yang ingin bergabung dengan program ini, tetapi lokasinya jauh dari kelompok yang sudah ada. Kegiatan ini biasanya dilakukan ketika ada rekomendasi dari peserta program, atau ada peserta program yang berpindah rumah dan 


\begin{tabular}{|c|c|c|c|c|}
\hline $\begin{array}{c}\text { Jurnal Penelitian \& } \\
\text { PPM }\end{array}$ & ISSN: 2442-448X & Vol 4, No: 2 & Hal: $129-389$ & Juli 2017 \\
\hline
\end{tabular}

masih berminat mengikuti program ini. Jadi dilihat dari segi availability, kegiatan ini tidak selalu ada, hanya saat-saat tertentu saja.

Ditinjau dari segi accessibility, program pelayanan keuangan mikro Bina Swadaya di kecamatan Kiaracondong berlokasi di gang Simpang dan gang Masjid. Area ini cukup strategis karena tedapat dua pasar tradisional dan banyak terdapat usaha mikro. Dilaksanakannya program pelayanan keuangan mikro Bina Swadaya di wilayah ini memudahkan masyarakat dalam memperoleh pinjaman untuk mengembangkan usahanya. Jadi pemilihan area gang Simpang dan gang Masjid ini telah memenuhi unsur accessibility.

Dilihat dari segi responsiveness, di wilayah gang Simpang dan gang Masjid ini terdapat rentenir yang selalu berkeliling setiap harinya, untuk mencari orang yang ingin meminjam uang. Selain itu di lokasi ini tidak terdapat layanan keuangan lain selain bank dan rentenir. Hal ini membuat masyarakat meminjam uang kepada tetangga atau kerabatnya. Jadi pemilihan area gang Simpang dan gang Masjid ini telah memenuhi unsur responsiveness.

Dilihat dari segi relevance, gang Simpang dan gang Masjid ini banyak masyarakat yang berprofesi sebagai pedagang. Mengingat di area ini terdapat dua pasar tradisional dan banyak terdapat usaha mikro, maka di wilayah seperti ini biasanya banyak usaha mikro yang membutuhkan pinjaman modal guna mengembangkan usahanya. Jadi pemilihan area gang Simpang dan gang Masjid ini telah memenuhi unsur relevance.

Dilihat dari segi productivity, kegiatan pemilihan area ini biasanya dilakukan oleh $\mathrm{CO}$ yang memperoleh rekomendasi dari peserta program yang dilayaninya. Dapat dikatakan kegiatan pemilihan area ini cukup efisien, karena tidak banyak menggunakan sumberdaya. Dilihat dari segi perfomance, staf Bina Swadaya dalam melakukan pemilihan area selalu mempertimbangkan kondisi sosial lingkungan tersebut, areanya harus banyak kegiatan usaha mikro atau masyarakat yang memiliki usaha mikro. Apabila tidak ada usaha mikro maka lingkungan tersebut tidak dilayani.

\section{Tahap Sosialisasi}

Setelah dilakukan pemilihan area, maka dilakukan kegiatan sosialisasi bagi masyarakat yang berminat mengikuti program ini. Dilihat dari segi availability, kegiatan sosialisasi hanya dilakukan ketika ada pembentukan kelompok baru atau ada peserta program yang baru

Dilihat dari segi accessibility, kegiatan sosialisasi ini awalnya dilakukan kepada istri dari tokoh masyarakat setempat. Hal ini bertujuan agar memudahkan dalam menyebarkan informasi program ini. Istri tokoh masyarakat setempat lebih mengetahui dan memiliki pengaruh terhadap masyarakat yang dipimpinnya.

Dilihat dari segi productivity, kegiatan sosialisasi ini dilakukan oleh BM serta didampingi oleh CO. Dalam kegiatan sosialisasi ini tidak banyak sumber daya yang digunakan, hanya ada beberapa brosur yang diberikan kepada calon peserta program agar lebih memahami syarat dan prosedur program ini. Dilihat dari segi perfomance, kegiatan sosialisasi ini dilakukan dengan sejelasjelasnya, staf Bina Swadaya menerangkan pelaksanaan dan tatacara programnya, sementara itu calon peserta program mendengarkan dan dibebaskan bertanya apabila ada hal yang tidak dipahami.

\section{Tahap Pembentukan Kelompok}

Bagi masyarakat yang berminat bergabung dengan program ini, diharuskan untuk membentuk kelompok. Dilihat dari segi availability, pembentukan kelompok dilakukan apabila disekitar rumah calon peserta program tidak ada kelompok yang sudah terbentuk. Apabila sudah ada kelompok, maka calon peserta tersebut dapat bergabung dengan kelompok yang sudah ada. Pembentukan kelompok dilakukan apabila calon peserta program berjumlah minimal lima orang. Apabila kurang dari lima orang maka, calon peserta program dimasukkan ke dalam kelompok yang sudah ada. Pada dasarnya kegiatan pembentukan kelompok ini merupakan syarat bagi calon peserta program yang ingin bergabung, jadi kegiatan ini selalu dilakukan sehingga memenuhi unsur availability.

Dilihat dari segi accessibility, pembentukan kelompok biasanya dilakukan pada waktu dan tempat yang telah disepakati sebelumnya. Hal ini agar memudahkan calon peserta program menghadiri pembentukan kelompok, sehingga diharapkan seluruh calon peserta program dapat menghadiri kegiatan ini. Walaupun dari segi tempat dan waktu pelaksanaan kegiatan pembentukan kelompok ini mudah 
diakses, namun masih ada masyarakat yang potensial menjadi peserta program tetapi tidak dapat bergabung. Prosedur yang mengharuskan peserta program berusia maksimal 60 tahun, menyebabkan tidak semua masyarakat terlayani. Walaupun 60 tahun merupakan usia yang lanjut, namun usia tersebut masih dapat beraktivitas secara normal. Jadi dapat dikatakan prosedur ini menghambat masyarakat yang potensial untuk menjadi peserta program, sehingga dapat dikatakan dari segi accessibility kegiatan pembentukan kelompok ini belum tepenuhi.

Dilihat dari segi responsiveness, Bagi ketua kelompok dengan pertemuan ini memudahkan dalam hal mengkoordinir anggota kelompoknya. Mengingat ketua kelompok memiliki tanggung jawab terhadap anggota kelompoknya. Bagi peserta program yang baru bergabung, kadang mereka belum memahami pengisian formulir pengajuan kredit, melalui kelompok peserta tersebut dapat bertanya kepada ketua kelompok atau rekannya. Selain itu, kelompok menjadi ajang silaturahmi diantara peserta program. selama ini peserta program jarang berkumpul karena kesibukannya masing-masing. Jadi kegiatan pembentukan kelompok ini sesuai dengan unsur responsiveness.

Dilihat dari segi relevance, kegiatan pembentukan kelompok ini pembentukan kelompok ini bertujuan untuk memudahkan peserta program dalam membayar angsuran pinjaman dan menabung. Peserta program tak perlu mendatangi kantor Bina Swadaya, cukup menghadiri pertemuan kelompok saja. Terkadang peserta program berhalangan hadir, mengingat angsuran pinjaman harus dibayar, maka peserta program dapat menitipkan angsurannya kepada ketua kelompok atau anggota kelompok yang lain. Jadi pembentukan kelompok ini sesuai dengan unsur relevance.

Dilihat dari segi productivity, kegiatan pembentukan kelompok ini biasanya tidak memakan waktu yang lama. Calon peserta program biasanya menemui staf Bina Swadaya dan menyatakan minat untuk bergabung, kemudian staf akan memberikan nomor telpon yang dapat dihubungi. Apabila calon peserta program sudah berjumlah lima orang, maka dilakukan kesepakatan untuk dilakukan pertemuan, hingga akhirnya calon peserta program tersebut membentuk kelompok. Jadi kegiatan pembentukan kelompok ini dapat dikatakan sesuai dengan unsur productivity, karena mudah, cepat dan tidak banyak menggunakan sumberdaya. Dilihat dari segi perfomance, $\mathrm{CO}$ selalu menghadiri pertemuan yang telah disepakati sebelumnya. Pemilihan ketua kelompok tempat dan waktu pertemuan diserahkan kepada calon peserta program, CO sifatnya hanya memediasikan saja. Jadi kegiatan pembentukan kelompok ini telah sesuai dengan unsur perfomance.

\section{Tahap Menabung}

Sebelum mengajukan pinjaman, peserta program diharuskan menabung terlebih dahulu. Dilihat dari segi availability, kegiatan menabung ini rutin dilakukan setiap minggunya dalam pertemuan kelompok.

Dilihat dari segi accessibility, kegiatan menabung ini wajib dilaksanakan oleh peserta program. Peserta program minimal menabung sebesar lima ribu rupiah setiap membayar angsuran pinjaman. jumlah tersebut cukup mudah dijangkau oleh peserta program, mengingat kegiatan menabung ini dilakukan per minggu. Jadi dapat dikatakan kegiatan menabung ini memenuhi unsur accessibility. Dilihat dari segi responsiveness, kebanyakan peserta program merasakan kesulitan menyimpan uang di rumah karena pada akhirnya uangnya selalu habis terpakai. Kegiatan menabung ini membuat peserta program lebih disiplin karena tabungannya hanya dapat diambil ketika hari pembayaran angsuran pinjaman saja. Jadi dapat dikatakan kegiatan menabung ini telah memenuhi unsur responsiveness.

Dilihat dari segi relevance, tujuan diadakannya kegiatan menabung ini untuk membiasakan diri peserta program agar menyisihkan uang yang dimilikinya guna memenuhi kebutuhan mendadak. Kegiatan menabung ini perlu dibiasakan karena pada umumnya peserta program belum menyadari manfaat dari menabung. Bagi mereka yang utama adalah kebutuhan sehari-hari terpenuhi dan angsuran pinjaman pinjaman. Sementara itu, pendapatan dari usaha mikro tidaklah menentu, tak selalu dagangan mereka habis terjual. Fungsi kegiatan menabung ini adalah untuk memenuhi kebutuhan ketika usaha sedang sepi pembeli. Jadi, kegiatan menabung ini dapat dikatakan relevance.

Dilihat dari segi productivity, kegiatan menabung ini tidak banyak menggunakan sumberdaya. Jadi dapat dikatan kegiatan menabung 


\begin{tabular}{|c|c|c|c|c|}
\hline $\begin{array}{c}\text { Jurnal Penelitian \& } \\
\text { PPM }\end{array}$ & ISSN: 2442-448X & Vol 4, No: 2 & Hal: $129-389$ & Juli 2017 \\
\hline
\end{tabular}

ini telah memenuhi unsur productivity karena dilakukan secara efisien, tidak banyak menggunakan sumberdaya. Dilihat dari segi perfomance, pelaksanaan kegiatan menabung ini belum dilaksanakan sesuai dengan prosedurnya. Masih ada peserta program yang tidak rutin menabung. CO tidak melarang peserta program yang tidak rutin menabung, namun tidak akan menaikkan jumlah pinjaman yang diajukan berikutnya. Jadi, kegiatan menabung ini belum memenuhi unsur perfomance.

\section{Tahap Pemberian Pinjaman}

Setelah peserta program menabung selama enam minggu berturut-turut, maka peserta program dapat mengajukan pinjaman. Dilihat dari segi availability, Bina Swadaya merupakan lembaga sosial yang memiliki sumber kuangan yang kuat dan tanpa donor, hasil dari menjalankan tujuh jenis kegiatannya. Kekuatan finansial tersebut dapat memenuhi pinjaman seluruh pesertanya. Selain memiliki sumber keuangan yang besar, pengembalian pinjaman dari peserta program juga cukup bagus.

Dilihat dari segi accessibility, kegiatan pemberian pinjaman syarat-syaratnya dapat dikatakan mudah dipenuhi. Peserta program hanya mengisi formulir dan menyertakan fotokopi KTP suami istri dan fotokopi kartu keluarga (KK) saja. Angsuran pinjaman dibayarkan setiap minggu dan diangsur selama satu tahun atau lima puluh kali angsuran. Angsuran ini lebih ringan jika dibandingkan dengan angsuran yang ditetapkan oleh rentenir, yang biasanya angsuran pinjaman dibayarkan setiap minggu namun jangka waktunya hanya sebulan atau tiga bulan. Jadi dapat dikatakan kegiatan pemberian pinjaman ini mudah diakses oleh peserta program dan biayanya masih terjangkau, jadi dapat dikatakan kegiatan pemebrian pinjaman ini telah memenuhi unsur accessibility.

Dilihat dari segi responsiveness, pemberian pinjaman dilakukan oleh Bina Swadaya untuk membantu peserta program dalam mengembangkan usahanya. Awalnya peserta program mengalami kesulitan dalam memperoleh pinjaman. Peserta program biasanya meminjam uang kepada kerabat atau tetangganya. Namun kini sudah jarang kerabat atau tetangga yang memberikan pinjaman, akibatnya peserta program beralih meminjam kepada rentenir. Meminjam kepada rentenir dirasakan berat karena bunganya tinggi dan waktu pengembalian pinjamannya cepat. Peserta program memilih bergabung dengan program ini karena angsurannya ringan, jangka waktunya satu tahun dan ada asuransinya. Jadi kegiatan pemberian pinjaman ini telah memenuhi unsur responsiveness.

Dilihat dari segi relevance, pemberian pinjaman ini memudahkan peserta program dalam memperoleh pinjaman. Kenaikan harga barang, kebutuhan yang semakin mahal dan bertambah, membuat peserta program membutuhkan pinjaman agar usahanya dapat berkembang atau minimal tetap stabil. Umumnya peserta program masih mencampur antara modal dengan konsumsi, sehingga pendapatan yang diperoleh cenderung lebih banyak digunakan untuk memenuhi kebutuhan, sehingga modal usaha mereka berkurang. Pemberian pinjaman ini membuat peserta program tetap dapat berjualan dan dapat memenuhi kebutuhannya. Jadi pemberian pinjaman telah memenuhi unsur relevance.

Dilihat dari segi productivity, kegiatan pemberian pinjaman ini dilakukan di kantor Bina Swadaya. Banyak peserta program yang tempat tinggalnya jauh dari kantor Bina Swadaya, sehingga mereka harus mengeluarkan ongkos untuk mencapai kantor Bina Swadaya. Jadi, kegiatan pemberian pinjaman ini belum memenuhi unsur productivity. Dilihat dari segi perfomance, pemberian pinjaman ini tetap diberikan kepada peserta program yang tidak rutin menabung dan tidak menghadiri pertemuan kelompok. bagi peserta program yang tidak rutin menabung atau menabung dengan jumlah seadanya, maka peserta tersebut tidak dapat mengajukan pinjaman dalam jumlah yang lebih besar dari pinjaman yang sebelumnya. Sementara bagi peserta program yang jarang menghadiri pertemuan kelompok masih dapat mengajukan pinjaman, apabila peserta tersebut rutin membayar angsuran pinjamannya. Jadi, kegiatan pemberian pinjaman ini belum memenuhi unsur perfomance.

\section{Tahap Pengembalian Pinjaman}

Pengembalian pinjaman dilakukan seminggu setelah peserta program menerima pinjaman. Dilihat dari segi availability, kegiatan pengembalian pinjaman ini rutin dilakukan setiap minggunya. CO selalu menghadiri pertemuan kelompok, sehingga peserta program dapat membayar angsuran pinjamannya. Jadi kegiatan 


\begin{tabular}{|c|c|c|c|c|}
\hline $\begin{array}{c}\text { Jurnal Penelitian \& } \\
\text { PPM }\end{array}$ & ISSN: 2442-448X & Vol 4, No: 2 & Hal: $129-389$ & Juli 2017 \\
\hline
\end{tabular}

pengembalian pinjaman ini telah memenuhi unsur availability. Dilihat dari segi accessibility, kegiatan pengembalian pinjaman ini dilakukan di rumah ketua kelompok. Rumah ketua kelompok biasanya lokasinya tak jauh dari rumah peserta program, minimal hanya berbeda RT saja. Waktu pelaksanaan pengembalian pinjaman juga disesuaikan dengan kegiatan para peserta program, agar peserta program dapat membayar angsuran pinjamannya, tanpa meninggalkan aktivitasnya. Jadi kegiatan pengembalian pinjaman ini telah memenuhi unsur accessibility.

Dilihat dari segi responsiveness, kegiatan pengembalian pinjaman ini harus dilakukan setiap minggunnya oleh peserta program. Terkadang ada peserta program yang merasakan keberatan dengan angsuran pinjaman atau bunganya. Peserta program tidak dapat memberikan masukan mengenai bunga dan angsurannya, mengingat $\mathrm{CO}$ sifatnya hanya menjalankan tugasnya saja, sementara kebijakan mengenai bunga dan angsurannya merupakan kebijakan pusat. Jadi dapat dikatakan kegiatan pengembalian pinjaman ini belum memenuhi responsiveness. Dilihat dari segi relevance, kegiatan pengembalian pinjaman yang dilakukan setiap minggu dirasakan ringan oleh peserta program. Jangka waktu pengembalian selama satu tahun, membuat peserta program tidak merasa terburu-buru atau dikejar hutang. $\mathrm{CO}$ yang melakukan penagihan juga melayani peserta program dengan sepenuh hati, tanpa ada unsur kekerasan. Jadi kegiatan pengembalian pinjaman ini telah memenuhi unsur relevance.

Dilihat dari segi productivity, kegiatan pengembalian pinjaman yang dilakukan dalam pertemuan kelompok. Hal ini membuat efisien waktu. CO tidak perlu mendatangi rumah peserta program satu-persatu, peserta program pun tak harus mengeluarkan biaya. Jadi, kegiatan pengembalian pinjaman ini telah memenuhi unsur productivity.

\section{Tahap Pencapaian Tujuan}

Tahap terakhir yang harus dianalisis adalah tahap keluaran (output). Keluaran adalah karakteristik klien pada saat lembaga selesai memberikan pelayanan terhadap klien. Karakteristik klien dapat diketahui dengan membandingkan keadaan peserta program sebelum dan sesudah bergabung dengan program pelayanan keuangan mikro Bina Swadaya ini. Selain karakteristik klien, faktor yang harus diperhatikan dalam menilai keluaran lembaga adalah service effectiveness. Service effectiveness yaitu setiap pelayanan yang diberikan lembaga terhadap klien harus berkaitan dengan pencapain tujuan program, dengan demikian pelayanan yang diberikan menjadi terarah dan sesuai dengan tujuan yang ingin dicapai.

Adapun tujuan yang ingin dicapai dalam program ini antara lain, melayani kebutuhan keuangan masyarakat, meningkatkan tabungan masyarakat, menciptakan lapangan kerja bagi masyarakat, membuat orang memiliki aset, membebaskan jeratan rentenir, memobilisasi sumberdaya setempat, meningkatkan daya beli masyarakat, memandirikan masyarakat dan mengatur ketersedian modal. Diantara tujuantujuan tersebut hanya tujuan untuk menciptakan lapangan kerja bagi masyarakat saja yang belum terlaksana, sedangkan tujuan yang lain sudah terlaksana sesuai dengan apa yang dirasakan oleh peserta programnya.

Pada dasarnya tujuan-tujuan tersebut merupakan aspek keluaran atau hasil yang ingin dicapai oleh Bina Swadaya dalam melaksanakan program pelayanan keuangan mikro di kecamatan Kiaracondong. Ditinjau dari faktor service effectiveness dapat diketahui bahwa, setiap pelayanan yang diberikan oleh Bina Swadaya kepada peserta program pada dasarnya mengarah kepada tujuan dari program ini. Pelayanan kredit mikro yang diberikan Bina Swadaya kepada peserta program bertujuan untuk melayani kebutuhan keuangan masyarakat, membuat orang memiliki aset, membebaskan jeratan rentenir, meningkatkan daya beli masyarakat, memandirikan masyarakat, mengatur ketersedian modal, serta menciptakan lapangan kerja bagi masyarakat.

Layanan kredit mikro ini juga bermanfaat bagi peserta program untuk memperoleh uang tambahan. Kebutuhan hidup yang terus mengalami kenaikan membuat kondisi usaha peserta program terganggu. Tak jarang modal usaha terserap ke dalam pemenuhan kebutuhan konsumsi. Agar usaha tetap berlangsung peserta program memerlukan uang tambahan baik itu untuk menutupi kebutuhan tersebut, atau untuk menutupi modal usaha yang terserap dalam memenuhi kebutuhan. Program pelayanan keuangan mikro ini kemudian menjadi sumber keuangan bagi peserta program untuk memperoleh uang tambahan 


\begin{tabular}{|c|c|c|c|c|}
\hline $\begin{array}{c}\text { Jurnal Penelitian \& } \\
\text { PPM }\end{array}$ & ISSN: 2442-448X & Vol 4, No: 2 & Hal: $129-389$ & Juli 2017 \\
\hline
\end{tabular}

tersebut. Dengan demikian, pemberian pinjaman yang diberikan Bina Swadaya dapat mengatur ketersedian modal dan membuat daya beli masyarakat tetap terjaga.

Maksud dari Bina Swadaya memberikan pinjaman kepada peserta program adalah agar modal bertambah, sehingga usaha mereka menjadi berkembang. Berkembangnya usaha diharapkan dapat membuka usaha baru atau menggunakan pekerja, sehingga dapat membuka lapangan kerja baru. Namun tujuan ini belum terlaksana, karena peserta program lebih memilih untuk mengelola usahanya sendiri ketimbang harus menambah pekerja, yang tentunya akan mengurangi pendapatan mereka. Salah satu upaya yang dilakukan peserta program untuk mengembangkan usahanya adalah dengan membeli peralatan yang dapat menunjang usaha mereka. Pada akhirnya pembelian alat-alat produksi ini membuat peserta program memiliki aset.

Program pelayanan keuangan mikro Bina Swadaya juga menyediakan layanan tabungan. Tujuan diadakannya layanan tabungan oleh Bina Swadaya adalah untuk meningkatkan tabungan masyarakat. Umumnya peserta program menyisihkan uang sisa belanjanya di rumah. Mereka lebih memilih menyimpan uang di rumah karena ada persepsi bahwa menabung di bank jumlah uangnya harus besar, jika jumlahnya sedikit mereka merasa malu kepada petugas bank.

Program pelayanan keuangan mikro Bina Swadaya seluruh pesertanya merupakan ibu rumah tangga yang memiliki usaha mikro. Tujuannya adalah agar usaha yang digelutinya dapat berkembang dan produktivitasnya meningkat. Apabila produktivitas ibu rumah tangga meningkat, maka kebutuhan anaknya dapat dipenuhi dan perekonomian keluarga akan meningkat. Secara perlahan tingkat ketergantungan keuangan terhadap suaminya akan sedikit berkurang dan mereka menjadi lebih mandiri. Selain bertujuan untuk meningkatkan produktivitasnya, pemilihan Ibu rumah tangga sebagai peserta program juga disebabkan karena ibu rumah tangga cenderung memiliki banyak waktu luang. Banyaknya waktu luang membuat ibu rumah tangga sering berkumpul dengan temantemannya. Hal ini tentunya memudahkan dalam proses sosialisasi program, karena informasi yang diperoleh ibu rumah tangga biasanya lebih cepat tersebar, sehingga dapat memobilisasi sumberdaya setempat agar bergabung dengan program ini.

\section{PENUTUP}

Program pelayanan keuangan mikro Bina Swadaya sedikit berbeda dengan program-program pemberian kredit yang kini marak dilakukan oleh berbagai lembaga. Program pelayanan keuangan mikro Bina Swadaya ini tidak menyertakankan kegiatan pembinaan kepada anggota yang mengikuti program tersebut meskipun melibatkan community worker/pendamping dalam proses yang dilakukan. Hal ini dimaksudkan agar para peserta program dapat langsung menggunakan uang pinjaman tersebut untuk mengembangkan usahanya. Hasil yang nampak dari program ini ibu-ibu yang memiliki usaha mikro dapat terbantu usahanya. Tidak adanya pembinaan menimbulkan pro dan kontra, sebab tidak adanya pembinaan menyebabkan peserta program tidak mendapatkan pengetahuan dan keterampilan baru. Hal ini perlu merupakan masukan terhadap pengembangan program pemberdayaan masyarakat dengan model yang sama maupun berbeda. Sebab program pengembangan UMKM maupun pengentasan kemiskinan tidak hanya terkait dengan modal atau materi.

\section{DAFTAR PUSTAKA}

\section{Buku- buku}

Adi, Isbandi Rukminto. 2003. Pemberdayaan, Pengembangan Masyarakat dan Intervensi Komunitas, Depok: Lembaga Penerbitan Fakultas Ekonomi UI.

Adi, Isbandi Rukminto. 2005. Ilmu Kesejahteraan Sosial dan Pekerjaan Sosial, Pengantar Pada Pengertian dan Beberapa pokok Bahasan, Depok: FISIP UI Press.

Raharjo, ST. 2015. Assessment untuk Praktik Pekerjaan Sosial dan Kesejahteraan Sosial. Bandung: Unpad Press 2015. Dasar Pengetahuan Pekerjaan Sosial. Bandung: Unpad Press. 2015. Keterampilan Pekerjaan Sosial: Dasar-dasar. Bandung, Unpad Press.

Sjaifudian, Hetifah, Dedi Haryadi dan Maspiyati. 1995. Strategi dan Agenda Pengembangan Usaha Kecil, Bandung: Yayasan Akatiga. 


\begin{tabular}{|c|c|c|c|c|}
\hline $\begin{array}{c}\text { Jurnal Penelitian \& } \\
\text { PPM }\end{array}$ & ISSN: 2442-448X & Vol 4, No: 2 & Hal: $129-389$ & Juli 2017 \\
\hline
\end{tabular}

Soetarso. 1993. Kesejahteraan Sosial, Pelayanan Sosial dan Kebijakan Sosial, Jakarta: Bina Aksara.

Suharto, Edi.1997. Pembangunan Sosial, Kebijakan Sosial dan Pekerjaan Sosial: Spektrum Pemikiran, Bandung: Lembaga Studi Pembangunan STKS.
Suharto, Edi. 2008. Kebijakan Sosial Sebagai Kebijakan Publik, Bandung: Alfabeta.

Suharto, Edi. 2009. Membangun Masyarakat Memberdayakan Rakyat, Bandung: Refika Aditama. 